\title{
Ultrastructural analysis of in vitro direct and indirect organogenesis
}

\author{
BEATRIZ APPEZZATO-DA-GLÓRIA ${ }^{1}$ and SILVIA R. MACHADO²
}

(received: October 9, 2002; accepted: March 18, 2004)

\begin{abstract}
Ultrastructural analysis of in vitro direct and indirect organogenesis). This is a comparative study of the ultrastructural characteristics of the cells involved in the organogenesis in vitro of Bauhinia forficata Link (indirect system) and Glycine max (L.) Merrill (direct system). B. forficata calli after 30 days culture and G. max meristemoids after 10 days culture were prepared for ultrastructural analysis using conventional methods. Concentrically arranged rough endoplasmic reticulum (RER) and plastids containing starch grains were seen during G. max and B. forficata organogenesis. The amitotic process, the presence of plastids around the nucleus and nuclear envelope with conspicuous pores were found in B. forficata.
\end{abstract}

Key words - amitosis, leguminous, meristemoids, morphogenesis

RESUMO - (Análise ultra-estrutural da organogênese in vitro direta e indireta). Este é um estudo comparativo das características ultra-estruturais das células envolvidas na organogênese in vitro de Bauhinia forficata Link (sistema indireto) e Glycine max (L.) Merrill (sistema direto). Calos de B. forficata, após 30 dias de cultura, e meristemóides de G. max, após 10 dias de cultura, foram preparados para as análises ultra-estruturais usando métodos convencionais. Retículo endoplasmático rugoso (RER) arranjado concentricamente e plastídeos contendo grãos de amido foram observados durante a organogênese de $G$. max e $B$. forficata. O processo amitótico, a presença de plastídeos ao redor do núcleo e de envelope nuclear com poros conspícuos foram observados apenas em $B$. forficata.

Palavras-chave - amitose, leguminosas, meristemóides, morfogênese

\section{Introduction}

The understanding of plant organogenesis and the initial developmental stages of meristemoids require observation of subcellular level changes and their correlation with biochemical alterations (PihakashiMaunsbach et al. 1993).

Studies on ultrastructural alterations during organogenesis in vitro to characterize the meristemoidal cells responsible for bud formation are scarce (Villalobos et al. 1985, Pihakashi-Maunsbach et al. 1993, Arai et al. 1997). These studies do not make comparative analyses between the direct and indirect regeneration systems or relate the ultrastructural aspects to the organogenic potential. Some authors, however, have attempted to relate ultrastructural characteristics to embryogenic potential (Konar et al. 1972, Radojevic et al. 1975, Vujicic et al. 1979).

Histological studies of Bauhinia forficata Link and Glycine max (L.) Merrill have demonstrated that

\footnotetext{
1. Universidade de São Paulo, Escola Superior de Agricultura Luiz de Queiroz, Departamento de Ciências Biológicas, Caixa Postal 9, 13418-900 Piracicaba, SP, Brasil.

2. Universidade Estadual Paulista, Instituto de Biociências, Departamento de Botânica, Caixa Postal 510, 18618-000 Botucatu, SP, Brasil.

3. Corresponding author: bagloria@esalq.usp.br
}

in vitro plant regeneration occurred throughout organogenesis (Vieira \& Appezzato-da-Glória 2001). Glycine max regenerated by direct organogenesis, with shoot buds originating from cotyledonary node epidermal and subepidermal tissue, and Bauhinia forficata Link regenerated by indirect organogenesis. In these species, histological examination revealed that shoots also developed from superficial tissue layers, and that the pattern of shoot origin and development is very similar to that previously described in literature for other leguminous species (McClean \& Grafton 1989, Jackson \& Hobbs 1990, Nauerby et al. 1991, Mohamed et al. 1992, Malik \& Saxena 1992).

This study is an analysis of the ultrastructural characteristics of the cells involved in the organogenesis in vitro of Bauhinia forficata (indirect system) and Glycine max (direct system).

\section{Material and methods}

Tissue culture - Bauhinia forficata Link calli were collected from $1 \mathrm{~cm}$ long hypocotyls excised from in vitro growing plants. The explants were cultured in 1/2 MS (Murashige \& Skoog 1962) basal medium supplemented with $3.0 \%$ (w/v) sucrose, $2.3 \mathrm{~g} \mathrm{~L}^{-1}$ phytagel (Sigma) and $4.0 \mathrm{mg} \mathrm{L}^{-1} \mathrm{BAP}$ (benzylaminopurine). The $\mathrm{pH}$ was adjusted to 5.8 prior to autoclaving. The cultures were incubated at $25 \pm 2{ }^{\circ} \mathrm{C}$ in a 16-hour photoperiod, and with $30 \mu \mathrm{molm}^{-2} \mathrm{~s}^{-1}$ irradiance 
provided by Philips cool white fluorescent tubes. Glycine $\max ($ L.) Merrill meristemoids were collected from cotyledonary nodes devoid of axillary buds used as explants. The explants were cultured in $1 / 2$ MS basal medium supplemented with $3.0 \%$ (w/v) sucrose, $7.0 \mathrm{~g} \mathrm{~L}^{-1}$ agar (Merck), $0.56 \mathrm{mg} \mathrm{L}^{-1} \mathrm{BAP}$ (benzylaminopurine). The $\mathrm{pH}$ was adjusted to 5.8 prior to autoclaving. The cultures were incubated at $27 \pm 2{ }^{\circ} \mathrm{C}$ in a 16-hour photoperiod, and with $30 \mu \mathrm{molm}^{-2} \mathrm{~s}^{-1}$ irradiance provided by Philips cool white fluorescent tubes. Ultrastructural analysis - Bauhinia forficata Link calli after 30 days culture and G. max meristemoids after 10 days culture were fixed in $2.5 \%$ glutaraldehyde, post-fixed in $1 \% \mathrm{OsO}_{4}$, both prepared in phosphate buffer $0.1 \mathrm{M}, \mathrm{pH} 7.3$. The samples were dehydrated in an ethanol alcoholic series and embedded in Araldite resin (Silva \& Machado 1999). Ultra-thin sections were stained with uranyl acetate and lead citrate (Reynolds 1963) and examined with a Philips TEM 100 operated at $80 \mathrm{kV}$.

\section{Results}

The Bauhinia forficata meristemoidal cells are vacuolated. These generally undergo unequal division resulting in different sized daughter cells (figure 1). These cells show a spherical nucleus, a large nucleolus, and a nuclear envelope with conspicuous pores (figure 2). There are abundant amiloplasts usually located around the nucleus (figure 2). Vesicles of electron-dense content can be seen in peripheral cytoplasm and adjacent to the plasma membrane (figure 4) and tonoplast. The rough endoplasmic reticulum (RER) may be concentrically arranged (figure 5) or extensive (figure 6). The most striking ultrastructural feature is the appearance, in newly-divided cells, of fragments of interphasic chromatin scattered within the cytoplasm (figures 3,6 ). These fragments may be totally or partially surrounded by a double membrane (figure 6). Another major aspect in some cells is the nuclear envelope disintegration without simultaneous chromatin condensation. Dictyosome are frequent; each one is composed of 8 to 10 dilated cisternae (figure 7).

The Glycine max subepidermal cells, which start division resulting in the formation of meristemoids, show a large central vacuole, and nuclei of different shapes and irregular outlines (figure 8). These cells generally undergo unequal division so that daughter cells are of different sizes. The wall between the daughter cells is relatively thinner than the mother cell wall (figure 12). The daughter cells show a central nucleus with one nucleolus and abundant cytoplasm rich in ribosomes (figures 8,9). The dictyosomes are composed of four to six cisternae and are active in vesicle production (figures 9, 14). Vesicles and other membraneous materials can be seen inside the vacuoles (figure 9). Dilated regions of chloroplasts containing material of different electron-density to stroma and dividing chloroplasts are common in these cells (figure 10). The chloroplasts have an extensive internal membrane system, with one or more starch grains (figure 13). The cytoplasmic connections through plasmodesmata are numerous in daughter cells (figure 11), indicating intensive interaction through the symplast. One of the major ultrastructural features is the RER concentric arrangement (figures 12-14), which seems to be closely associated with the dictyosomes (figure 14), plastids, and mitochondria (figure 13). The mitochondria are generally oval or round and contain an electron-dense matrix and well-developed cristae (figure 13). Many dividing mitochondria can be seen (figure 15).

\section{Discussion}

The meristemoids in Bauhinia forficata and Glycine max do not originate from typical meristemoidal cells but from highly vacuolated cells, similar to those observed by Villalobos et al. (1985) during organogenesis in Pinus radiata. In general, these vacuolated cells divide unequally, giving rise to daughter cells of different sizes. This frequently occurs in wounded meristems, where the vacuolated cells show nuclei adjacent to the trauma area during prophase (Sinnott \& Bloch 1941).

In both studied species, the wall between the daughter cells is extremely thinner than that of the mother cell. This has been reported in other organogenic (Villalobos et al. 1985) and embryogenic (Button et al. 1974) processes. In G. max, the cytoplasmic connections, through plasmodesmata, are numerous in the daughter cells, indicating an intense interaction via symplast. It was also observed in Zea mays apical region cells of somatic embryos (Fransz \& Schel 1991).

Comparison between the B. forficata and G. max meristemoids shows that the nuclear envelope of B. forficata has numerous and conspicuous pores. The nuclear pores are dynamic structures, their number being directly proportional to protein production and transport (Garrido et al. 1995).

In G. $\max$, the presence of dividing chloroplasts and mitochondria during the initial phases of meristemoid formation allows even distribution of these organelles in the daughter cells during cytokinesis. In G. max, the mitochondria are abundant and contain an electron dense matrix and well-developed cristae. These features have been described in embryogenic systems as being associated with higher metabolic 
activity, usually related to higher respiratory rate (Profumo et al. 1987, Fransz \& Schel 1991, Jasik et al. 1995, Canhoto et al. 1996).

In B. forficata and G. $\max$ meristemoidal cells, vesicles and other membranous materials inside the vacuoles indicate an autophagic process. Autophagic vacuoles have been linked to the renewal or extension of the cellular lytic compartment, which is associated to drastic changes in the cellular genetic program (Fransz \& Schel 1991).
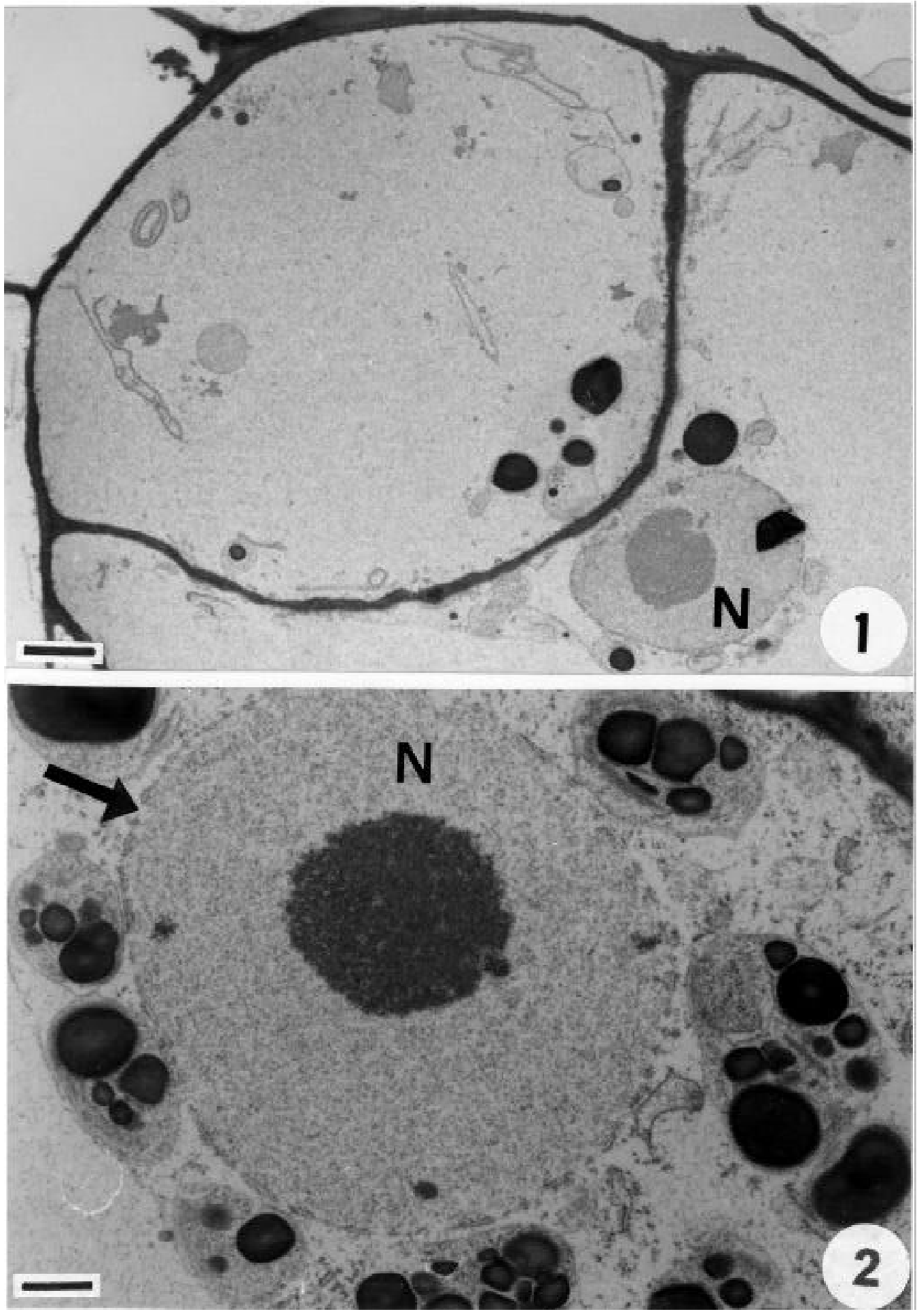

Figures 1-2. Bauhinia forficata meristemoidal cells. 1. Newly-divided cells. 2. Nuclear (N) envelope pores (arrow); plastids containing starch grains are distributed around the nuclei. $\mathrm{Bar}=3 \mu \mathrm{m}(1), 1 \mu \mathrm{m}(2)$. 

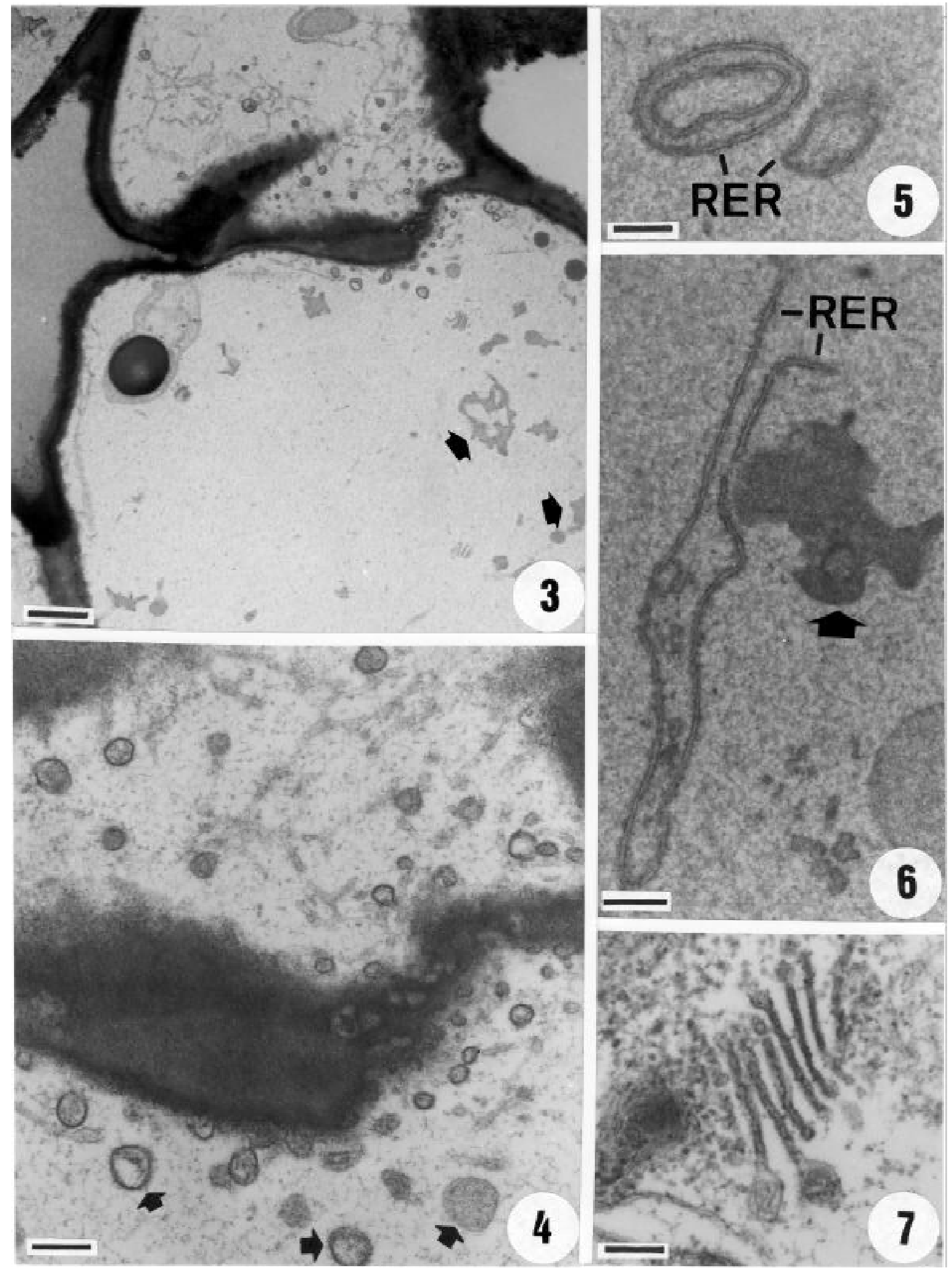

Figures 3-7. Bauhinia forficata newly-divided meristemoidal cells. 3. Fragments of interphasic chromatin (arrows). 4. Vesicles (arrows) of electron-dense content are seen in the peripheral cytoplasm and adjacent to the plasma membrane. 5. Concentric profiles of rough endoplasmic reticulum (RER). 6. Non-concentric profiles of RER and fragments of interphasic chromatin partially involved by a double membrane (arrow). 7. Secretory dictyosome. Bar $=1.3 \mu \mathrm{m}(3), 0.3 \mu \mathrm{m}(4), 0.5 \mu \mathrm{m}(5), 0.5 \mu \mathrm{m}(6)$, $0.2 \mu \mathrm{m}$ (7). 

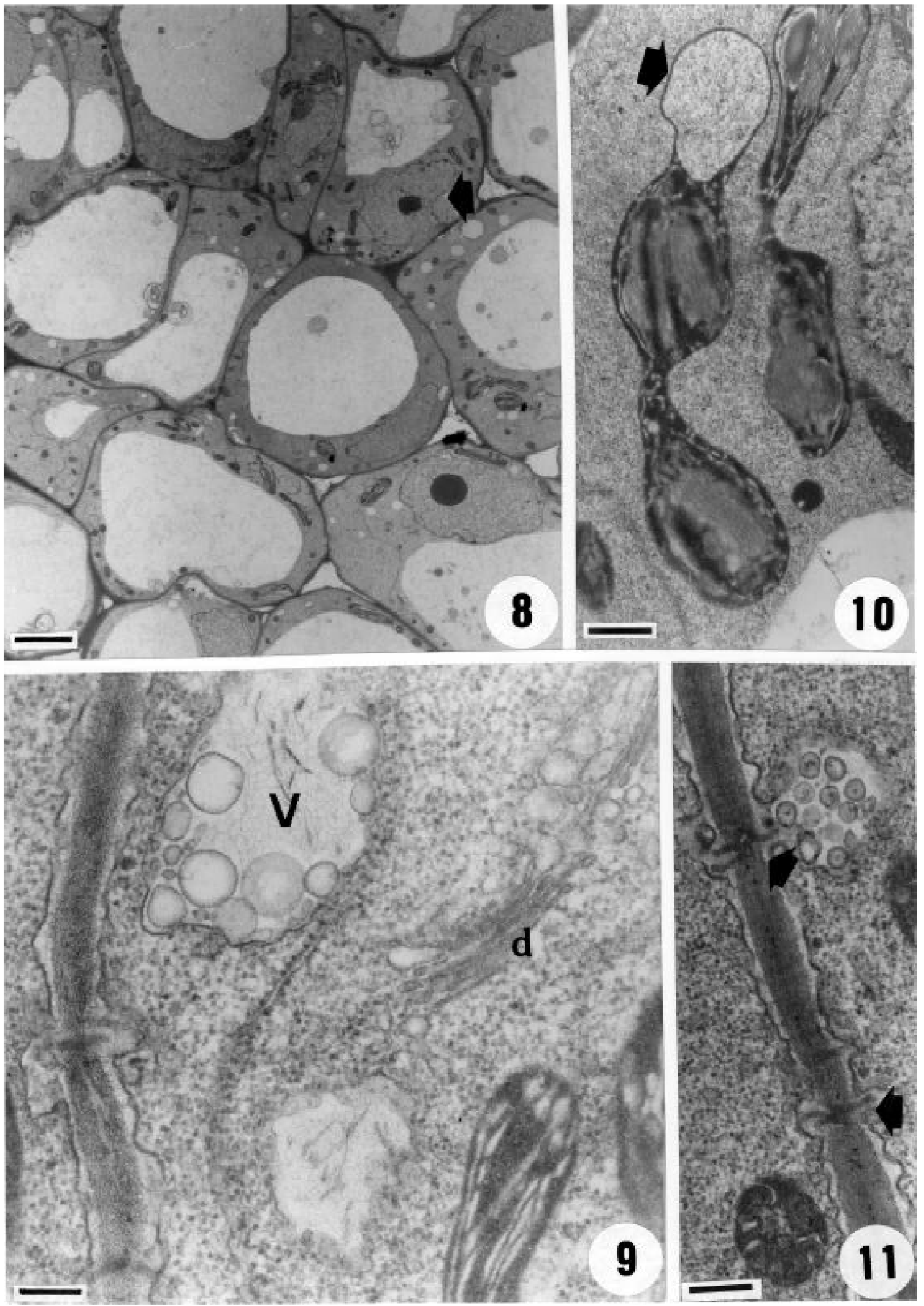

Figures 8-11. Glycine max meristemoidal cells. 8. Newly-divided cells of irregular nucleus shape (arrow). 9. Autophagic vacuoles (V) and dictyosomes (d). 10. Dividing chloroplasts showing dilation-containing material of different electron-density to stroma (arrow). 11. Cytoplasmic connections (arrows) through plasmodesmata between the daughter cells. Bar $=4 \mu \mathrm{m}(8), 0.2 \mu \mathrm{m}(9)$, $0.6 \mu \mathrm{m}(10), 0.2 \mu \mathrm{m}(11)$. 

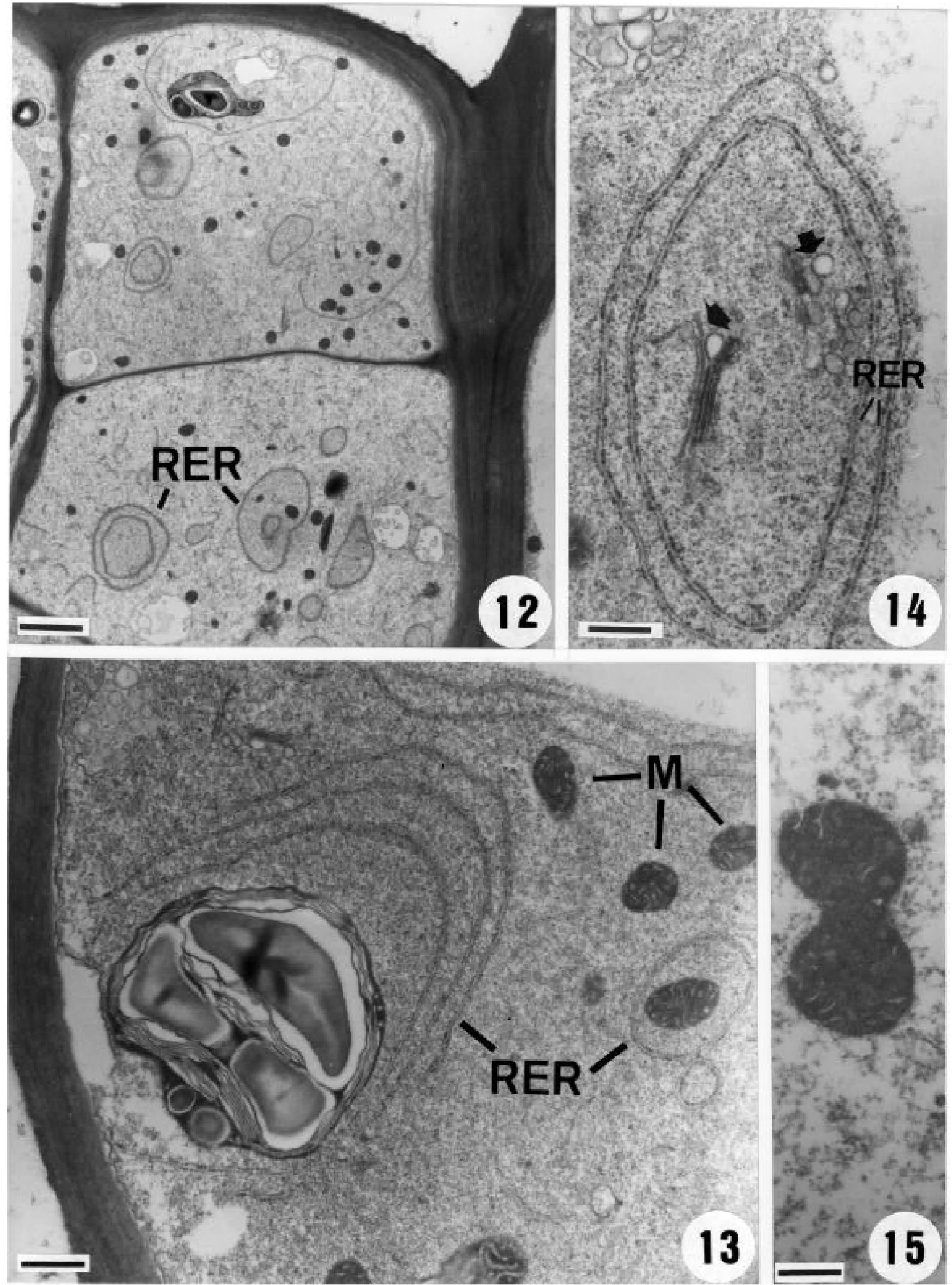

Figures 12-15. Glycine max meristemoidal cells. 12. Cell walls between daughter cells are thinner than the mother cell wall. 13. Rough endoplasmic reticulum (RER) associated with amiloplastid and mitochondria (M). 14. Concentric profiles of RER surrounding secretory dictyosome (arrow). 15. Dividing mitochondria. Bar =2.3 $\mu \mathrm{m}(12), 0.6 \mu \mathrm{m}(13), 0.3 \mu \mathrm{m}(14), 0.2 \mu \mathrm{m}(15)$. 
In the two systems analyzed in this study, meristemoidal cell differentiation is associated with higher metabolic activity characteristics, such as an increase in the number of polysomes and mitochondrial cristae, and a proliferation of dictyosomes and RER segments (Profumo et al. 1987, Fransz \& Schel 1991, PihakashiMaunsbach et al. 1993).

In B. forficata and G. max, the dictyosomes are active in producing many vesicles, which can be seen near the plasma membrane. The increase in number of dictyosomes, typically involved in the production of cell wall material, may be connected with an accelerated synthesis of cell wall compounds after one day of culture, as seen in Brassica napus by PihakashiMaunsbach et al. (1993).

In both species, although the dividing cells of the meristemoids show plastids containing starch grains, it is only in B. forficata that these plastids are usually located around the nucleus. In G. $\max$ and in Pinus radiata (Villalobos et al. 1985), both having direct regeneration systems, the chloroplasts are randomly distributed throughout the cytoplasm.

In G. max, chloroplasts with dilations, containing material of a similar electron-density to the cytoplasm, are similar to those observed by Jasik et al. (1995) in non-embryogenic calli. In these calli, some plastids showed cytoplasms in cavity. Other ultrastructural changes in plastids: secondary dedifferentiation of mature chloroplasts, thylakoid swelling and disruption, plastid elongation and increase in size were described in Mammillaria gracillis cultivated in vitro (Poljuha et al. (2003). According to the authors, plastids are organelles very sensitive to the artificial environment in the culture.

Starch grains in the plastids of meristemoidal dividing cells seems to be a common feature of organogenesis, which has been reported in literature describing ultrastructural changes in this regeneration system (Villalobos et al. 1985, Pihakashi-Maunsbach et al. 1993, Ovecka et al. 2000). This feature has frequently been related to the acquisition of embryogenic potential, as embryogenic cells usually contain starch grains (Maheswaran \& Williams 1985, Profumo et al. 1987). In this context, why cannot the occurrence of starch in the plastids be seen as a feature associated with the acquisition of organogenic potential?

However, starch degradation during bud primordium formation, as described in literature (Arnold 1987, Mangat et al. 1990, Pihakashi-Maunsbach et al. 1993, Arai et al. 1997) as well as in analysis performed on G. max (Vieira \& Appezzato-da-Glória 2001) suggest that starch has a closer association with the high nutritional requirement of cell populations, independent of their regeneration system (Arnold 1987).

The usual RER concentric profile, seen during the initial stages of G. max and B. forficata meristemoids, may be involved in protein synthesis in response to rapid cellular growth, and not associated with the potential of a morphogenetic system, as suggested for embryogenic processes by Radojevic et al. (1975), Vujicic et al. (1979), and Canhoto et al. (1996). As can be seen in this study, reporting the occurrence of RER concentric profiles in organogenetic systems should be more common.

Therefore, two ultrastructural characteristics generally associated only with the embryogenic potential, RER in concentric profiles, and plastids containing starch, have been associated only with the embryogenic potential. As this has also been observed in B. forficata and G. max organogenesis, these characteristics may reveal a high synthesis capacity associated with the reorganization of growth pattern during induction of somatic morphogenesis.

In $B$. forficata, which displays indirect organogenesis, the appearance of interphasic chromatin fragments in the cytoplasm in newly-divided meristemoid cells indicate the occurrence of amitosis (nuclear fragmentation). According to Wilson's definition (apud Bregoli et al. 1997) amitosis is the fragmentation of the nucleus into two parts, but as observed in this study, fragmentation may be multiple. Amitotic division apparently occurs at the transition from a differentiate cell state to one of disorganized growth, as they frequently appear as an initial response to wounding caused by excision. In fact, in Vicia faba (Cionini et al. 1978), Phaseolus vulgaris (Fasseas \& Bowes 1980), and Helianthus tuberosus (Bregoli et al. 1997), amitotic divisions occur mainly during the initial callus growth stages. Nuclear fragmentation, which occurs during the initial stages of callogenesis followed by mitosis, may be a major source of chromosomal variation in tissue cultures (Bayliss 1980). If this chromosomal variation in plant tissue cultures caused by amitotic processes can generate a genetic variability called somaclonal variation (Larkin \& Scowcroft 1981), then direct organogenesis, as seen in G. max in this study, could be the best indication to obtain transgenic plants regenerated from transformed explants.

Acknowledgments - This research was supported by the Fapesp (Fundação de Amparo à Pesquisa do Estado de São Paulo) and CNPq (Conselho Nacional de Desenvolvimento 
Científico e Tecnológico). The authors are grateful to staff of the Centro de Microscopia Eletrônica, Unesp, Botucatu, for the use of laboratory facilities.

\section{References}

ARAI, M., SAITO, T., KANEKO, Y. \& MATSUSHIMA, H. 1997. Cellular origin and ultrastructural changes of regenerating shoots from tobacco (Nicotiana tabacum) internodes cultured in vitro. Physiologia Plantarum 99:523-528.

ARNOLD, S. VON. 1987. Effect of sucrose on starch accumulation in and adventitious bud formation on embryos of Picea abies. Annals of Botany 59:15-22.

BAYLISS, M.W. 1980. Chromosomal variation in plant tissues in culture. International Review of Cytology 11A:113 -144.

BREGOLI, A.M, CROSTI, P., CAVALLINI, A., CIONINI, G., DELLUCA, S., MALERBA, M., NATALI, L., SERAFINIFRACASSINI, D. \& D'AMATO, F. 1997. Nuclear DNA distribution and amitotic processes in activated Helianthus tuberosus tuber parenchyma. Plant Biosystems 131:3-12.

BUTTON, J., KOCHBA, J. \& BORNMAN, C. H. 1974. Fine structure of embryoid development from embryogenic ovular callus of 'Shamouti' orange (Citrus sinensis Osb.). Journal of Experimental Botany 25:446-457.

CANHOTO, J.M., MESQUITA, J.F. \& CRUZ, G.S. 1996. Ultrastructural changes in cotyledons of pineapple guava (Myrtaceae) during somatic embryogenesis. Annals of Botany 78:513-521.

CIONINI, P.G., BENNICI, A. \& D'AMATO, F. 1978. Nuclear cytology of callus induction and development in vitro: I. Callus from Vicia faba cotyledons. Protoplasma 96:101-112.

FASSEAS, C. \& BOWES, B.G. 1980. Ultrastructural observations on proliferating storage cells of mature cotyledons of Phaseolus vulgaris L. cultured in vitro. Annals of Botany 46:143-152.

FRANSZ, P.F. \& SCHEL, H.N. 1991. An ultrastructural study on the early development of Zea mays somatic embryos. Canadian Journal of Botany 69:858-865.

GARRIDO, D., VICENTE, O., HEBERLE-BORS, E. \& RODRIGUEZ-GARCÍA, M.I. 1995. Cellular changes during the acquisition of embryogenic potential in isolated pollen grains of Nicotiana tabacum. Protoplasma 186:220-230.

JACKSON, J.A. \& HOBBS, S.L. 1990. Rapid multiple shoot production from cotyledonary node explants of pea (Pisum sativum L.). In vitro Cellular Developmental Biology 26:835-838.

JASIK, J., SALAJOVA, T. \& SALAJ, J. 1995. Developmental anatomy and ultrastructure of early somatic embryos in European black pine (Pinus nigra Arn.). Protoplasma 185:205-211.
KONAR, R.N., THOMAS, E. \& STREET, H.E. 1972. Origin and structure of embryoids arising from the epidermal cells of Ranunculus sceleratus L. Journal of Cell Science 11:77-93.

LARKIN, P. \& SCOWCROFT, W.R. 1981. Somaclonal variation: a novel source of variability from cell cultures for plant improvement. Theoretical and Applied Genetics 60:197-214.

MAHESWARAN, G. \& WILLIAMS, E.G. 1985. Origin and development of somatic embryoids formed directly on immature embryos of Trifolium repens in vitro. Annals of Botany 56:619-630.

MALIK, K.A. \& SAXENA, P.K. 1992. Somatic embryogenesis and shoot regeneration from intact seedlings of Phaseolus acutifolius A. Gray, P. aureus (L.) Wilczek, P. coccineus L., and P. wrightii L. Plant Cell Reports 1:163-168.

MANGAT, B.S., PELEKIS, M.K. \& CASSELLS, A.C. 1990. Changes in the starch content during organogenesis in vitro cultured Begonia rex stem explants. Physiologia Plantarum 79:267-274.

MCCLEAN, P. \& GRAFTON, K.F. 1989. Regeneration of dry bean (Phaseolus vulgaris L.) via organogenesis. Plant Science 60:117-122.

MOHAMED, M.F., READ, P.E. \& COYNE, D.P. 1992. Dark preconditioning, CPPU, and thidiazuron promote shoot organogenesis on seedling node explants of common and faba beans. Journal of the American Society for Horticultural Science 117:668-672.

MURASHIGE, T. \& SKOOG, F. 1962. A revised medium for rapid growth and bioassays with tobacco tissue cultures. Physiologia Plantarum 15:473-497.

NAUERBY, B., MADSEN, M., CHRISTIANSEN, J. \& WYNDAELE, R. 1991. A rapid and efficient system for pea (Pisum sativum), suitable for transformation. Plant Cell Reports 9:676-679.

OVECKA, M., BOBÁK, M. \& SAMAJ, J. 2000. A comparative structural analysis of direct and indirect shoot regeneration of Papaver somniferum L. in vitro. Journal of Plant Physiology 157:281-289.

PIHAKASHI-MAUNSBACH, K., NYGAARD, K.B., JENSEN, K.H. \& RASMUSSEN, O. 1993. Cellular changes in early development of regenerating thin cell layer-explants of rapeseed analysed by light and electron microscopy. Physiologia Plantarum 87:167-176.

POLJUHA, D., BALEN, B., BAUER, A., LJUBESIC, N. \& KRSNIK-RASOL，M. 2003. Morphology and ultrastructure of Mammillaria gracillis (Cactaceae) in in vitro culture. Plant Cell, Tissue and Organ Culture 75:117-123.

PROFUMO, P., GASTALDO, P. \& RASCIO, N. 1987. Ultrastructural study of different types of callus from leaf explants of Aesculus hippocastanum L. Protoplasma 138:89-97. 
RADOJEVIC, L., VUJICIC, R. \& NESKOVIC, M. 1975. Embryogenesis in tissue culture of Coryllus avellana L. Zeitschrift für Pflanzenphysiologie 77:33-41.

REYNOLDS, E.S. 1963. The use of lead citrate and high $\mathrm{pH}$ as an electron-opaque stain in electron microscopy. Journal of Cell Biology 17:208-212.

SILVA, E.M.J. \& MACHADO, S.R. 1999. Ultrastructure and cytochemistry of pearl gland in Piper regnellii (Miq.) C. DC.- Piperaceae. Nordic Journal of Botany 19:623-634.

SINNOTT, E.W. \& BLOCH, R. 1941. Division in vacuolate plant cells. American Journal of Botany 28:225-232.
VIEIRA, M.L.C. \& APPEZZATO-DA-GLÓRIA, B. 2001. Fundamentos e aplicações da cultura de tecidos no melhoramento. In Recursos genéticos e melhoramento plantas. (L.L. Nass, A.C.C. Valois, I.S. Melo \& N.C. ValadaresInglis, eds.). Fundação MT, Rondonópolis, p.911-938.

VILLALOBOS, V.M., YEUNG, E.C. \& THORPE, T.A. 1985. Origin of adventitious shoots in excised radiata pine cotyledons cultured in vitro. Canadian Journal of Botany 63:2172-2176.

VUJICIC, R., RADOJEVIC, L. \& NESKOVIC, M. 1979. Regular alignment of membrane ribosomes in embryogenic tissue of Paulownia tomentosa. Zeitschrift für Pflanzenphysiologie 91:53-56. 
